\title{
MATURIDADE SEXUAL EM CALLINECTES ORNATUS ORDWAY, 1863 EXPLORADO COMERCIALMENTE EM SÃO FRANCISCO DO PARAGUAÇU, BAHIA, BRASIL
}

\author{
Cardim, R.W.S. ${ }^{1,}$; Souza, E.R. ${ }^{2}$ \& Rocha, S.S. ${ }^{1}$ \\ ${ }^{1}$ Universidade Federal do Recôncavo da Bahia (UFRB), CCAAB, Laboratório de Bioecologia de Crustáceos. \\ ${ }^{2}$ Empresa de Assistência Técnica e Extensão Rural do Ceará (EMATERCE). \\ *Autor correspondente: robert.wagner18@outlook.com
}

O siri Callinectes ornatus Ordway, 1863 ocorre desde a Carolina do Norte (EUA) até o Rio grande do Sul (Brasil), em estuários com maior salinidade, geralmente em fundos arenosos ou lodosos. Na Baía de Todos os Santos é comercializada na forma de "catado", após ser processada para a retirada do exoesqueleto. Apesar da importância econômica e grande abundância de C. ornatus no litoral do nordeste brasileiro, ainda há poucas estimativas do seu tamanho de maturação. Desta forma, objetivou-se estudar a maturidade sexual de C. ornatus na comunidade pesqueira de São Francisco do Paraguaçu, Bahia $\left(12^{\circ} 44^{\prime} 37,5^{\prime \prime} \mathrm{S} ; 38^{\circ} 52^{\prime} 26,3^{\prime \prime} \mathrm{W}\right)$. Os siris foram coletados com armadilhas, de agosto de 2013 a julho de 2014. Todos os exemplares tiveram o sexo determinado, foram medidos em sua largura de carapaça (LC) e verificados quanto o grau de aderência do abdômen ao cefalotórax e estágio de maturação das gônadas. Dessa forma, ocorreu a separação dos siris em quatro grupos demográficos: macho jovem (MJ), macho adulto (MA), fêmea jovem (MJ), fêmea adulta (FA). O tamanho médio da primeira maturação (L50\%) foi determinado tanto a partir dos critérios fisiológicos como morfológicos, por interpolação da equação obtida através da regressão logística na condição do indivíduo (imaturo = 0; maduro = 1) versus a largura da carapaça. Ao todo, foram analisados 1471 exemplares, dos quais 943 eram machos $(9,25 \%$ jovens; 54,9 adultos) e 528 eram fêmeas ( $8,23 \%$ jovens e $27,7 \%$ adultas). Nenhuma fêmea ovígera foi encontrada nas amostras, indicando que estas provavelmente migram para outras áreas após a fecundação. A distribuição dos animais por classe de tamanho revelou predomínio de indivíduos com gônadas imaturas nas menores classes, enquanto aqueles com gônadas em desenvolvimento e maduras predominaram nas classes superiores. O L50\% morfológico foi estimado em 42,42 mm para machos e 42,14 mm para as fêmeas. Já o L50\% fisiológico foi estimado em 55,15 mm para machos e 40,43 mm para fêmeas. Nossos resultados demonstraram que há sincronia na maturidade morfológica e fisiológica nas fêmeas, o mesmo não ocorrendo nos machos. Por fim, para garantir o manejo sustentável da espécie, recomendamos que os pescadores de São Francisco do Paraguaçu capturem indivíduos com LC superior a 55,0 mm.

Palavras-chave: Brachyura, razão sexual, recrutamento, maturidade sexual. 